choice of a suitable location for the laboratory to the two men who know so well the ecological and other features of our deserts.

The report of this advisory board embraces an account of the journey along the Mexican border in search of a suitable site. There are twenty-nine fine photographic reproductions of typical desert landscapes, representing not only the features of the vegetation about Tucson, but also the more interesting ecological characteristics of the other deserts, which were visited, viz., the Tularosa desert of New Mexico, with its unique gypsum sand dunes; the deserts in the neighborhood of Torres and Guaymas, Mexico; the Colorado desert about Salton, Cal.; and the Grand Cañon of the Colorado in Arizona. In deciding upon Tucson for a laboratory site, regard was had for four requirements which an ideal site should possess : a distinct desert climate and flora, a flora that is rich and varied, accessibility, and habitability. In addition to these advantages, Tucson is the seat of the state university and agricultural experiment station, and its citizens cooperated enthusiastically in the enterprise - a matter of no small moment.

The chapter on the plant life of American deserts is introduced by a consideration of their meteorological and soil features; the most interesting table here is the one which gives the ratio between precipitation and evaporation. Instructive maps and soil analyses also illuminate this section. MacDougal's experiments on transpiration and temperature, which were conducted in the Arizona deserts near Flagstaff in 1898 , are also included, and suggest one of the fruitful lines of investigation which the new laboratory will make possible.

The report concludes with an excellent bibliography of desert literature, prepared by the resident investigator, Dr. W. A. Cannon. The references are grouped under four heads: general treatises, references relating to climate, references relating to soil, and references relating to water. This bibliography will prove of immense assistance to investigators at the laboratory, and to students of similar problems everywhere.

While one cannot predict the exact place which the new laboratory is to occupy in botanical research, it is our right to expect great things, particularly in physiology and ecology, in which investigators are coming more and more to feel the need of field experiments. We may not hope to torture a desert plant into revealing its secrets to us in our laboratories and greenhouses, but it may unfold the mysteries of its life to those who live with it day by day in its own haunts. It is likely too that morphologists and taxonomists will find the Desert Laboratory of much help.- H. C. CowLES.

\title{
Plant chemistry.
}

"THIS BOOK" is the outgrowth of instruction in chemistry given in the School of Agriculture of the University of Minnesota." It is intended for

${ }^{2}$ SNyder, Harry, The chemistry of plant and animal life. I2mo. pp. xvii + 406. New York City: The Macmillan Company. 1903. \$1.40. 
the use of students with no previous knowledge of chemistry. The first 154 pages are devoted to elementary chemistry. The headings of the remaining chapters will indicate the scope of the rest of the book. These are: the water-content and ash of plants; the non-nitrogenous organic compounds of plants; the nitrogenous organic compounds of plants; the chemistry of plant growth; composition of plants at different stages of growth; factors which influence the composition and feeding value of crops; composition of coarse fodders; wheat; maize; oats, etc.; mill- and by-products; roots, tubers, and fruits ; fermentation; chemistry of digestion and nutrition; rational feeding of animals; composition of animal bodies; rational feeding of men. Interspersed throughout the book are directions for numerous simple experiments, designed to be performed by the pupil.

The chapters on pure chemistry deal only with the most important elements and compounds which enter into the composition of plants and animals. The treatment, in this part of the book, is very elementary, and often decidedly dogmatic. Some statements occur which are not free from serious objection. Thus on page 3 : "It was believed, at one time, that metals, as copper, could be changed into gold, and other substances into different forms of matter. Aftermany centuries of experimenting it was found that this could not be done, and as a result the law of the indestructibility of matter was established." The "change of substances into different forms of matter" is one of the principal subjects of the chemist's study. On the other hand, the question of transmutation has no bearing on the doctrine of the conservation of matter. On page 4 we find: "The reasons for accepting the molecular structure of matter cannot be profitably taken up by the student of elementary chemistry." And on page 13: "The way in which atomic weights are obtained cannot at this stage of the work, be profitably considered." The subject is not considered later; but, nevertheless, the terms "atom" and " molecule" are constantly employed, as are also chemical formulas, which are introduced on the twelfth page. It is to be feared that the student will gain the idea that atomic weights and formulas are obtained in some mysterious way, and that the properties of substances are to be deduced from these data by some sort of algebraic manipulation. Thus on page 73 it is stated: "In the study of acids, bases, and salts the character of the compound can always be determined from the formula, as $\mathrm{Ca}(\mathrm{OH})_{2}$." The treatment of valence is equally objectionable. Under the heading "Impossible reactions," page $\mathrm{I}_{23}$, it is stated that in " the case of $\mathrm{BaSO}_{4}+2 \mathrm{HCl}$ no reaction can take place," because these substances are the products of the action of $\mathrm{BaCl}_{2}+$ $\mathrm{H}_{2} \mathrm{SO}_{4}$. This would seem to teach the impossibility of reversible reactions. Some statements are inaccurate. Thus, page 24: "Liquids are never weighed, but always measured;" page 40 , "Hydrogen is liquefied with greater difficulty than any other element." This ignores helium. On page 58 , speaking of water of crystallization, it is said: " Without this water crystals could not be formed." On page $\mathrm{I}_{1} 3$, benzene $\left(\mathrm{C}_{6} \mathrm{H}_{6}\right)$ is referred to as 
benzine and benzol; the term "benzine" is (correctly) used on page 110 to designate the petroleum product. On page 195 gum arabic and the gums of peach and cherry trees are mentioned as typical examples of gums. In the next line is the statement: "When treated with dilute acids the gums are converted into dextrose sugars and acid products." The gums mentioned as examples all give pentose sugars and not dextroses. Page 20I : "Beeswax, for example, is composed of palmitic and ethyl radicals." The chief constituent of beeswax is myricyl palmitate, not ethyl palmitate. The whole of page 20 is devoted to description of plates I and II. On page 267 plate III is mentioned. There are no plates in the book. On page 406 there is a table of "Corrections;" but no such errors exist on the pages indicated.

In spite of some faults, there is a judicious selection of subjects, and in the applied part of the book a clear and concise treatment of the matter presented. While the book is not recommended as a text for elementary chemistry, the applied portions should prove very useful to students of agriculture, and interesting to all who, having an elementary knowledge of chemistry, are concerned in the subject of plant and animal nutrition.- H. N. McCoy.

\section{The Bonn text-book.}

THE FACT that this book, ${ }^{3}$ addressed to college students, has reached its sixth edition in ten years is ample evidence of its popularity. One notices at once the name of Dr. G. Karsten instead of the late Dr. A. F. W. Schimper, who wrote the chapters on phanerogams for the previous editions. As before, the first three sections on morphology, physiology, and cryptogams, are treated by Strasburger, Noll, and Schenck respectively. In these three sections the sequence of topics and the method of treatment are practically the same as in the fifth edition, the principal revision appearing in the changes which have been necessary in order to keep the work fully abreast with recent contributions.

In the section on morphology the new figures and perhaps the most extensive revision of the text concerns the central cylinder of vascular plants. In the section on physiology the chapter on the "Stability of the plant body" has received a much more extended treatment than heretofore. More attention has also been given to ecology. In the cryptogams several new figures have been added, and slight changes, occasioned by recent studies, appear in the text.

In the treatment of the phanerogams one cannot speak of revision, for the entire section has been rewritten by Dr. G. Karsten. The gymnosperms receive more attention than previously. The arrangement of the angiosperms is practically that followed in Engler and Prantl's Pfanzenfamilien. By abbreviating the diagnoses of orders and families, Professor Karsten has

${ }^{3}$ Strasburger, E., Noli, F., Schenck, H., and Karsten, G., Lehrbuch der Botanik für Hochschulen, 6th ed. Imp. 8vo. pp. viii + 59I. figs. 741 . Jena: Gustav Fischer. 1904. $M 7.50$. 


\section{$2 \mathrm{BHL}$ Biodiversity Heritage Library}

Mccoy, H N . 1904. "The Chemistry of Plant and Animal Life. Harry Snyder." Botanical gazette 37(4), 309-311. https://doi.org/10.1086/328483.

View This Item Online: https://www.biodiversitylibrary.org/item/39610

DOI: https://doi.org/10.1086/328483

Permalink: https://www.biodiversitylibrary.org/partpdf/223163

\section{Holding Institution}

Missouri Botanical Garden, Peter H. Raven Library

\section{Sponsored by}

Missouri Botanical Garden

\section{Copyright \& Reuse}

Copyright Status: Public domain. The BHL considers that this work is no longer under copyright protection.

This document was created from content at the Biodiversity Heritage Library, the world's largest open access digital library for biodiversity literature and archives. Visit BHL at https://www.biodiversitylibrary.org. 